\title{
Digital Trends of Financialization of Public-Private Partnership Projects in Social and Economic Systems Management
}

\author{
Yuzvovich L.I.* Isakova N.Yu. Kadochnikova T. S. \\ Ural Federal University named after the first President of Russia B.N. Yeltsin, Yekaterinburg 620102, Russia \\ "Corresponding author. Email: yuzvovich@bk.ru
}

\begin{abstract}
In the conditions of global digitalization and managing social and economic systems, public-private partnership is, first of all, a mechanism for attracting private investment into the creation of the social infrastructure objects. Provision of the efficient management of state and municipal property, and increasing the quality of socially important services for population provided on its basis, is the main regional development direction. Digital trends of socially important public-private partnership projects financialization represent the economy functioning tool, characterizing advantages of financial deals in the common system of concession projects financing. In the conditions of serious lack of investment resources, the application of attractive forms of public-private partnership projects financialization in managing social and economic systems could give the investor serious benefits and provide the inflow of long-term investment into the national economy. This article deals with the consideration of digital trends of the forms of concession projects financing in terms of multi-variant financialization and the selection of optimal financial deals at the implementation of concession agreements.
\end{abstract}

Keywords: financialization, public-private partnership projects, digital trends, concession agreements

\section{INTRODUCTION}

The research rationale is distinguished by the need to study digital trends of public-private partnership projects financialization in managing social and economic systems. Today, methods of accurate and multi-variant developement and assessment of concession projects financing in terms of public-private partnership are in demand, which is the paper subject.

Actuality and discussible nature of theoretical and methodological background to the financialization of public-private partnership projects, the high practical importance of selecting forms and methods of financing of concession projects in a modern economic system set the goal and tasks, determined the choice of the study object and subject.

Public-private partnership (PPP) is one of the methods of developing social infrastructure based on the long-term interrelation of the state and business when the private party participates not only in design, financing, construction or reconstruction of the infrastructure object but also, its further operation (service provision on the object created) and/or maintenance In terms of economy, the goal of public-private partnership in terms of economy is stimulating the private investment attraction to the production of services, work, and consumer goods, that should be provided by public law institutions at the expense of the respective budgets, and the reduction of the state participation in economic turnover, when the business can perform same tasks in a more efficient manner. In terms of the law, this refers to interrelations of public-law entities (of the Russian Federation, RF subject, municipal structure) and private persons.

The concession agreement is one of the forms of investment attraction into the economy, used by many countries. In conditions of acute shortage of investment resources, the application of this form of investing, attractive for the investor, could provide significant benefits and create the long-term investment inflow into the national economy.

The concessionare taxation issue is one of the most important. It seems advisable to develop the special tax regime for the implementation of the concession agreement. Such possibility exists and does not contradict Part 5 of the Russian Tax Code. The feature of concession taxation is that the single concession tax or regular payments (royalties) are established for the concessionare. Concerning taxation of natural resources, separate features, taking into account the specifics of these resources, can be provided. The need for introducing the specific tax regime provides for legal and infrastructure features. 


\section{PRESENTATION OF THE MAIN RESEARCH MATERIAL WITH FULL SUBSTANTIATION OF THE SCIENTIFIC RESULTS OBTAINED, FORMULATION OF RECOMMENDATIONS}

The main advantages of the public-private partnership mechanism are given in Table 1. Advantages given in Table 1serve as an impulse for establishing relations based on public-private partnership agreements and concession agreements signed by them and which are civil law contracts in terms of their legal nature. Along with that, concession agreements are one of the public-private partnership forms (models). The method of executing public-private partnership agreements and concession agreements is tendering in the form of tender for the right to conclude the agreement.

Possible investment development options of any country can be reduced to a range of financial and economic models, where each model can be modified and specified in the context of the specific state. Economic literature provides no system characteristic of possible investment development models, but the specific tools are thoroughly examined in scientific publications of domestic and foreign scientists, economists, and lawyers.

The existing models of the private and public party interaction are given in Table 2; at the same time, various model modifications are not excluded or prohibited.

The implementation of the concession agreement project (Table 2) provides for the attraction of private financing. At this, the Federal Law "On Concession Agreements" permit undertaking the share of the costs for creation, and all or part of the costs of operation (maintenance) of the agreement object by the public party. Private financing of the CS project can be attracted from varipus sources. Money attraction forms can be as follows:

- budget co-financing;

- $\quad$ bank crediting;

- $\quad$ infrastructure bonds;

- $\quad$ project financing, etc.

Financial participation of the grantor, the public partner in the public-private partnership project can consist of:

- providing budget subsidies for compensating the part of the capital and current expenses of the concessionare, the private partner;

- guaranteeing the minimal level of loading (revenue position) of the agreement object;

- compensating the lack of the received income of the private partner (concessionare);

- $\quad$ provision of state and municipal guarantees. 
Table 1 Advantages of the public-private partnership mechanism [1]

\begin{tabular}{|c|c|}
\hline For public party & For private party \\
\hline $\begin{array}{l}\text { Possibility to attract the private investor to } \\
\text { the project creation financing allows } \\
\text { implementing the infrastructure projects } \\
\text { even if there is no sufficient volume of } \\
\text { budget funds without increasing the debt } \\
\text { load in the current period }\end{array}$ & $\begin{array}{l}\text { Fixing the conditions of interrelation } \\
\text { with the public party in terms of the } \\
\text { long-term agreement }\end{array}$ \\
\hline $\begin{array}{l}\text { Possibility to unite various stages (design, } \\
\text { construction, and operation) within one } \\
\text { project }\end{array}$ & $\begin{array}{l}\text { The possibility of receiving a land } \\
\text { plot, forest plot, water plot and/or plot } \\
\text { (of other water, forest, etc.) without } \\
\text { tenders for the implementation of } \\
\text { CPPP (CMPP) }\end{array}$ \\
\hline $\begin{array}{l}\text { Possibility to purchase not the object, but } \\
\text { the service due to payments tied to its } \\
\text { provision volume and quality, which also } \\
\text { contributes to the development of } \\
\text { competition in the socially important } \\
\text { services market. }\end{array}$ & $\begin{array}{l}\text { Possibility of the project co-financing } \\
\text { by a public party, receiving additional } \\
\text { guarantees (including minimal profit) }\end{array}$ \\
\hline $\begin{array}{l}\text { Possibility to use the private partner's } \\
\text { (concessionare's) resources and } \\
\text { competences for providing important } \\
\text { services, increasing their quality and } \\
\text { consumer satisfaction, the attraction of } \\
\text { new technologies }\end{array}$ & $\begin{array}{l}\text { The possibility to increase the project } \\
\text { income by providing additional paid } \\
\text { services and/or use of different } \\
\text { solutions that reduce costs at the stage } \\
\text { of creation or operation }\end{array}$ \\
\hline For public party & For private party \\
\hline $\begin{array}{l}\text { Transfer of the part of project risks to the } \\
\text { private partner (concessionare) }\end{array}$ & $\begin{array}{l}\text { Transfer of the part of project risks to } \\
\text { the public partner (concedent) }\end{array}$ \\
\hline Decrease of the state presence in economy & $\begin{array}{l}\text { Fixed in areas of activity that are } \\
\text { traditionally held by state }\end{array}$ \\
\hline $\begin{array}{l}\text { In case of the private initiative - the } \\
\text { possibility to delegate expenses related to } \\
\text { the project development, to the project } \\
\text { private initiator, and reduce the term of the } \\
\text { investor selection, with increasing the } \\
\text { efficiency of the property complex } \\
\text { management. }\end{array}$ & $\begin{array}{l}\text { In case of the private initiative - the } \\
\text { possibility to work through the project } \\
\text { structure independently and to offer } \\
\text { the draft agreement, to reduce the } \\
\text { agreement execution time }\end{array}$ \\
\hline
\end{tabular}

Different combinations of the ways of the project budget financing can be used in the agreement. At this, it is recommended to set the maximal amount of expenses and financial obligations of the grantor and the public partner in the agreement. Co-financing of expenses for the creating of the agreement object (capital grant provision) by the grantor and the public partner allows increasing the object investment attractiveness, reducing the volume of payments from the budget (if expected) at the operational stage, and the level of the tariff load on users, if income from the provision of paid services form a source of compensation for the concessionaire's and the private partner's investment. At this, the reasonability and volume of co-financing of their budget should be calculated based on the project features.

Bank crediting in the public private partnership. It is the most widespread loan financing source. At this, most of the banks set their own requirements to a partial investor concerning the availability of his/her own funds for project implementation (e.g., 20\% of total loan-based funding volume). Other conditions are possible: e.g., if the investor has no stock required, it is possible to negotiate with a credit institution on its entry into the private investor's share stock. Conditions of loan-based funding can also provide for the provision of the interest repayment respite at the stage of the agreement object creation, and various loan interest rates - higher at the creation stage (with the significant project risks) and lower - at the stage of the agreement object operation (when the project construction risks are already irrelevant). At this, mechanisms of attracting the concessionary financing (industry programs for interest rates subsidizing for loans attracted) can be used. 
Table 2: Models of interactions between the parties in terms of the concessional agreement [4]

\begin{tabular}{|c|c|}
\hline Form & Description \\
\hline BTO & $\begin{array}{c}\text { The private party performs the object } \\
\text { construction/reconstruction, delivers and } \\
\text { transfers ownership of the project to the public } \\
\text { partner, performs the object operation and } \\
\text { receives income from the operation. }\end{array}$ \\
\hline BOT/DBOT & $\begin{array}{c}\text { The private party performs the object } \\
\text { construction/reconstruction, receives } \\
\text { ownership of the project, performs the object } \\
\text { operation and receives income from the } \\
\text { operation, delivers and transfers ownership to } \\
\text { the public partner upon the agreement } \\
\text { expiration }\end{array}$ \\
\hline BOO/DBOO & $\begin{array}{l}\text { The private party performs the object design } \\
\text { and/or construction/reconstruction, performs } \\
\text { the object operation within the perms agreed } \\
\text { with the public party and receives income } \\
\text { from the operation, preserving ownership } \\
\text { upon the agreement expiration }\end{array}$ \\
\hline BOOT/DBOOT & $\begin{array}{l}\text { The private party performs the object design } \\
\text { and/or construction/reconstruction, performs } \\
\text { the object operation within the perms agreed } \\
\text { with the public party and receives income } \\
\text { from operation, delivers and transfers } \\
\text { ownership to the public partner upon the } \\
\text { agreement expiration }\end{array}$ \\
\hline $\begin{array}{c}\text { The private party performs the object design } \\
\text { and/or construction/reconstruction, and } \\
\text { delivers and transfers ownership to the public } \\
\text { partner for the reward. }\end{array}$ \\
\hline \\
\hline
\end{tabular}

Understanding the possibility to pretend for concessional bank financing (subsidizing loan interest rates by the state, etc.) after signing the concession agreement or PPP/MPP agreement, it is required to provide for conditions for distributing benefits from such concessional financing between public and private parties already at the agreement preparation stage. Otherwise, the private investor receives all the benefits from the specified concessionary financing. Due to this, with the purpose to use concessional bank financing, the agreement may provide for a mechanism for decreasing the extent of the public party participation in the project in case of its successful attraction into the project (e.g., reducing the amount of the subsidy provided by the RF subject).

With the purpose to ensure their interests in the case of the agreement amendment and termination of the agreement, including the project default, the financing organizations use the agreement between the creditors, the public party and the private investor - the direct agreement under which the rights of the latter can be used the security of fulfilling obligations to the creditors (e.g., in accordance with the Law on PPP, the object of the agreement may be pledged to the financing organization; moreover, other mechanisms can be provided for securing the rights of financing organizations, e.g., the financing organization's right to participate in the concessionaire replacement under Part 4, Article 5 of "Concerning the Constitutional Court of the Russian Federation"). The presence and content of a direct agreement is important for determining the possibility of attracting loan-based funding for the project implementation and its conditions [4].
Infrastructure bonds. One of PPP forms is a tool called infrastructure financing, implemented by issuing infrastructure bonds. This tool is new to Russia, and its implementation is prevented by the respective experience lack and disadvantages of the procedure and mechanism for providing state guarantees under it, together with poor regulation in the laws. In this case, potential investors are large financial funds, oriented at the conservative investment strategy. Possibility to attract funds of a large number of the investors rather cheaply makes infrastructure bonds one of the prospective private financing forms, including transport infrastructure projects. This problem requires to be worked out at the legislative level, in particular, completion and adoption of bills: "On peculiarities of investing into infrastructure with the use of infrastructure bonds" and "On the fundamentals of public-private partnerships in the Russian Federation subjects and municipal institutions and on amending the certain legislative acts of the Russian Federation." With regard to various types of infrastructure bonds, the following options can be implemented:

- $\quad$ in case of limited financial capabilities of local, regional and state budgets, issuance of bonds for the implementation of projects with the high potential level of yield (airports, seaports);

- $\quad$ in case of the low potential level of the yield of the projects, and at their social orientation, bonds of public companies with the coverage guarantee should be used; The Design Agreement is signed with the specialized design organization (SDO), that carries out emission. In order to reduce risks for potential investors, guarantees are 
issued for securities emitted. In case if infrastructure bonds are issued in RUB and oriented at the national market, such large financial funds as WEB, RF funds can be guarantors. State corporations, or the $\mathrm{R}$ subject itself. When issuing infrastructure bonds in foreign currency and entry into foreign markets, they can be International Bank for Reconstruction and Development (IBRD), European Bank for Reconstruction and Development (EBRD), etc., but, as it was stated earlier, due to sanctions, alternative financial funds, e.g., Arabic or Asian, should be searched. The more developed capital market will allow attracting larger volumes of financial resources at the lower value. But now, according to the draft, the nominal of infrastructure bonds cannot be specified in any other currency, except rouble. Besides guarantees, the fulfillment of obligations set by infrastructure bonds can be provided by the pledge of the future money requirements from the project forecasted money expenses. Concerning the remaining part of obligations or paying the notional value and obligations for paying income, the pledge can be represented by securities or real estate in accordance with the bill, or a bank guarantee can be provided. For monetary funds received from the emission of infrastructure bonds, acquired by high-qualified investors, SDO performs project works. The source of payment of infrastructure bonds and the moment of transfer of ownership of the project to the subject of the $\mathrm{RF}$ in accordance with the scheme offered will be different depending on the infrastructure project:

- if the project brings no income, repayment can be provided budget income items or the specific income type, such as transport tax. According to BC RF, the budget of the subjects of the Russian Federation provides for the accrual of tax income from transport tax $-100 \%$ under the normative. Consequently, the allocation of all proceeds from this tax on the territory of notional value and coupon payments under the infrastructure bonds. In the case specified, SDO delivers and transfers ownership of the finished infrastructure project to the subject of the Russian Federation immediately after construction completion;

- if the infrastructure object generates the cash flow, the notional value and the coupon income (using bonds with deferred coupon paymen is allowed) will be partially or fully repaid at the expense of the projectgenerated cash flow;
- ownership of the project providing for the payment of the notional share of infrastructure bonds and coupon income due to mixed financing, is delivered and transferred to the subject of the Russian Federation in accordance with the design agreement.

If the PPP project total cost exceeds 1 bln RUB due to the inclusion into quotation lists and earning capacity with inflation rate + risk bonus, such bonds can be interesting to institutional investors

The simplified procedure of the inclusion of these bonds into quotation lists (regulation of the Bank of Russia of February 24, 2016, No. 534-P "On listing at on-exchange trading") [5]. Infrastructure bonds of the concessionare issuer are included in the list of permitted assets for the investment of insurance assets and non-state pension funds. At this, concerning on-state pension funds, the concessionary investment order is provided (without the obligatory conformity of the rating of issuance of infrastructure bonds of the concessionare issuer to the level established by the Council Board of the Bank of Russia).

The term "infrastructure bonds" is rather not a legal term but an economic category demonstrating the belonging to the certain project types.

The first projects of paid highway construction with the use of infrastructure bonds are as follows:

- Road connecting St. Petersburg and Moscow, double of the existing M10;

- Western High-Speed Diameter (WHSD(in St. Petersburg);

- DoubleM-1 "Belarus" Moscow-Minsk, the investor OJSC "Glavnaya Doroga".

In 2010, there was registered the first issue of infrastructure materialized inconvertible bonds by the concessionare OJSC "Glavnaya Doroga" with the issue volume of 300 thousand pcs. with the notional value of 1 thousand RUB and the period of circulation of 1 year.

In Russia, there is also an alternative name - concession infrastructure bonds. Concession infrastructure bonds represent the tool of financing infrastructure projects, absolutely new to Russia. Such bonds are securities issued by the concessionare for financing the project under the concessional agreement [7]. 
Table 3 List and parameters of infrastructure bonds [6]

\begin{tabular}{|c|c|c|c|c|c|c|c|}
\hline issuer & $\begin{array}{l}\text { Issuanc } \\
\text { e series }\end{array}$ & $\begin{array}{l}\text { Placement } \\
\text { date }\end{array}$ & $\begin{array}{l}\text { Circulati } \\
\text { on term }\end{array}$ & $\begin{array}{c}\text { Constructi } \\
\text { on work in } \\
\text { progress, } \\
\text { bln RUB }\end{array}$ & $\begin{array}{c}\text { Moscow } \\
\text { Central Stock } \\
\text { Exchange Mosc } \\
\text { ow Branch list }\end{array}$ & $\begin{array}{l}\text { Lombard } \\
\text { list }\end{array}$ & $\begin{array}{l}\text { Listing level at } \\
\text { the Moscow } \\
\text { Central Stock } \\
\text { Exchange Mosc } \\
\text { ow Branch }\end{array}$ \\
\hline \multirow{4}{*}{ OJSC "Glavnaya Doroga" } & 01 & 04.06 .2010 & 1 & 0,3 & \multicolumn{3}{|c|}{ completed } \\
\hline & 03 & 22.11 .2010 & 18 & 8 & + & - & A1 \\
\hline & 06 & 12.12 .2012 & 16 & 8,2 & + & + & A1 \\
\hline & 07 & 20.11 .2012 & 17 & 1,4 & + & - & A1 \\
\hline \multirow{2}{*}{ CJSC "Upravleniye Othodami" } & 01 & 07.11 .2013 & 10,5 & 2,8 & + & - & A1 \\
\hline & 02 & 02.12 .2014 & 10,5 & 1 & + & - & A1 \\
\hline CJSC "Upravleniye Othodami-NN" & 01 & 27.06 .2012 & 10 & 1 & + & - & A1 \\
\hline \multirow{5}{*}{ OJSC "Zapadnyi Skorostnoy Diametr" } & 01 & 07.06 .2011 & 20 & 5 & + & + & A1 \\
\hline & 02 & 07.06 .2011 & 20 & 5 & + & + & A1 \\
\hline & 03 & 02.03 .2012 & 20 & 5 & + & + & A1 \\
\hline & 04 & 02.03 .2012 & 20 & 5 & + & + & A1 \\
\hline & 05 & 02.03 .2012 & 20 & 5 & + & + & A1 \\
\hline \multirow{2}{*}{ CJSC "Volga-Sport" } & 01 & 04.04 .2011 & 11 & 1,4 & + & - & A1 \\
\hline & 02 & 30.10 .2012 & 11 & 1,9 & + & - & A1 \\
\hline \multirow{2}{*}{$\begin{array}{c}\text { "Severo-Zapadnaya Kontsessionnaya } \\
\text { Kompaniya" LLC }\end{array}$} & 03 & 21.10 .2011 & 20 & 5 & + & + & A3 \\
\hline & 04 & 21.10 .2011 & 20 & 5 & + & + & A3 \\
\hline \multirow[b]{2}{*}{$\begin{array}{c}\text { GC "Rossiyskie Avtomobilnie } \\
\text { Dorogi" }\end{array}$} & 01 & 05.12 .2011 & 5 & 3 & + & + & A2 \\
\hline & 03 & 29.04 .2015 & 27 & 21,7 & \multicolumn{3}{|c|}{ closed subscription } \\
\hline
\end{tabular}

For the time being, 7 issuers issued 18 series of concession bonds with the total notional value of approximately 89 bln RUB, 16 issues with the total value of approximately 67.3 bln RUB were presented on the Moscow Exchange, and the listing level, as a rule, is A1. Four more issuers and 9 issues of concession infrastructure bonds were also included in the Lombard list of the Bank of Russia (Table $3)$.

Table 5 provides parameter sof emission for infrastructure bonds issued in Russia. The most concession projects using infrastructure bonds belong to the field of road infrastructure or housing and utilities infrastructure of federal and regional level almost in equal shares (Table 4). As a rule, the issuer of concession bonds, as shown in Table 4 , is the concessionaire, although, at the financial market, emissions of concession bonds are also available, performed by the organization performing the concessor's functions.

As a rule, the circle of potential investors is unlimited in placing concession infrastructure bonds. Issuance conditions are given on Figure 1. 
Table 4 Characteristics of concession projects [6]

\begin{tabular}{|c|c|c|c|}
\hline issuer & Issuance series & Concession project & Project level \\
\hline OJSC "Glavnaya Doroga" & $\begin{array}{c}01,03,06-07 \\
01\end{array}$ & $\begin{array}{l}\text { New access to MRHW from the federal } \\
\text { highway M-1 "Belarus" Moscow - Minsk } \\
\text { Utility infrastructure system - SHW } \\
\text { recycling and disposal system in Saratov } \\
\text { Region }\end{array}$ & $\begin{array}{l}\text { federal } \\
\text { regional }\end{array}$ \\
\hline $\begin{array}{l}\text { CJSC "Upravleniye } \\
\text { Othodami" }\end{array}$ & 02 & $\begin{array}{l}\text { Utility infrastructure system - SHW } \\
\text { recycling and disposal inter-municipal } \\
\text { system in Chuvashia }\end{array}$ & regional \\
\hline $\begin{array}{l}\text { CJSC "Upravleniye } \\
\text { Othodami-NN" }\end{array}$ & 1 & $\begin{array}{l}\text { Waste sorting plant with the inter- } \\
\text { municipal polygon for SHW unsuitable for } \\
\text { recycling in Nizhny Novgorod Region }\end{array}$ & regional \\
\hline $\begin{array}{c}\text { OJSC "Zapadnyi } \\
\text { Skorostnoy Diametr" }\end{array}$ & 01-05 & Zapadnyi Skorostnoy Diametr & federal \\
\hline \multirow{2}{*}{ CJSC "Volga-Sport" } & 01 & $\begin{array}{l}\text { Physical training and recreational centers } \\
\text { in Nizhny Novgorod Region }\end{array}$ & regional \\
\hline & 02 & $\begin{array}{l}\text { Indoor sports center with artificial ice for } \\
5000 \text { seats in Ulyanovsk Region } \\
\end{array}$ & regional \\
\hline $\begin{array}{l}\text { "Severo-Zapadnaya } \\
\text { Kontsessionnaya } \\
\text { Kompaniya" LLC } \\
\end{array}$ & 03-04 & $\begin{array}{l}\text { Motorway Minsk - St. Petersburg on the } \\
15-58 \mathrm{~km} \text { site }\end{array}$ & federal \\
\hline \multirow{2}{*}{$\begin{array}{l}\text { GC "Rossiyskie } \\
\text { Avtomobilnie Dorogi" }\end{array}$} & 01 & $\begin{array}{l}\text { Emission goal is financing } \\
\text { the indefinite range of projects: the } \\
\text { motorway M-4 "Don" is mentioned }\end{array}$ & federal \\
\hline & 03 & Central Ring Road in Moscow Region & federal \\
\hline
\end{tabular}

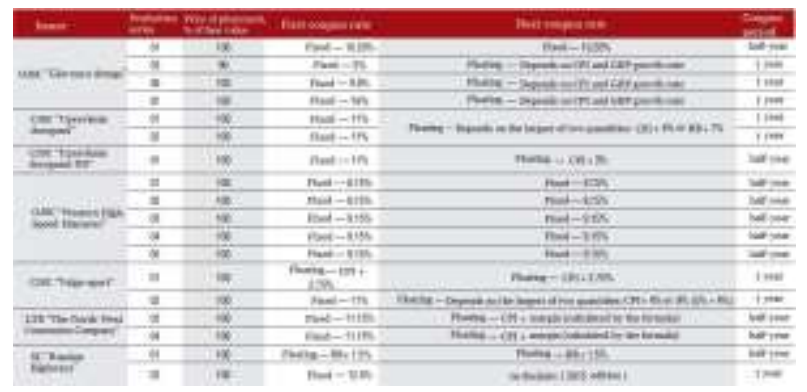

Figure 1 Issuance conditions for infrastructure bonds [6]

The conditions of concession bonds issues analyzed by us allow concluding te presence of a certain trend. Notional value is 1,000 RUB. The coupon period from six months to 1 year (the amount of coupons is determined based on the total bond circulation period and the total project duration). The coupon rate and/or the order of its determination is set directly in the listing prospectus or by the decision of the issuer's authorized agency. As a rule, the coupon combined rate is used, fixed and floating. But most often, the fixed rate is set for the first coupon, and for the following coupons, there is a floating rate, the final value of which is calculated by the formula with the use of such macro indicators as CPI, GDP and refinancing rate of the Bank of Russia. One of the parameters influencing the release quality is the condition of provision (Table 5)

Table 5 Conditions of provision [6]

\begin{tabular}{|c|c|c|c|}
\hline issuer & $\begin{array}{c}\text { Issuance } \\
\text { series }\end{array}$ & Condition on provision & Project level \\
\hline \multirow{3}{*}{ OJSC "Glavnaya Doroga" } & 01 & guarantee of LLC & federal \\
\hline & 06 & RF state guarantee & federal \\
\hline & 03,07 & not provided & federal \\
\hline $\begin{array}{l}\text { CJSC "Upravleniye Othodami" } \\
\text { CJSC "Upravleniye Othodami-NN" }\end{array}$ & $\begin{array}{c}01-02 \\
01\end{array}$ & $\begin{array}{l}\text { not provided } \\
\text { not provided }\end{array}$ & $\begin{array}{l}\text { regional } \\
\text { regional }\end{array}$ \\
\hline OJSC "Zapadnyi Skorostnoy Diametr" & $01-05$ & RF state guarantee & federal \\
\hline CJSC "Volga-Sport" & $01-02$ & not provided & regional \\
\hline "Severo-Zapadnaya Kontsessionnaya Kompaniya" LLC & 03-04 & RF state guarantee & federal \\
\hline GC "Rossiyskie Avtomobilnye Dorogi" & 01,03 & RF state guarantee & federal \\
\hline
\end{tabular}

The trend is as follows: the projects with the regional level are not provided, as a rule; the projects with the federal level are provided with the state guarantee of the Russian Federation (Table 5). 
Let us consider the world practice of infrastructure bonds use. For example, in the USA, infrastructure bonds are issued at the municipality level, and are called special target bonds. Such bonds are issued both with general coverage (general bonds) and with the provision of cash flows from certain projects of infrastructure objects construction (revenue bonds). For example, the creation of infrastructure bonds began which gave the possibility to rather small private investors to invest in large infrastructure projects [6].

As a rule, income from municipal bonds in the USA is non-taxable, which creates additional attractiveness for investors. Beside municipal bods, corporate infrastructure bonds, issued in terms of concession projects (analog of public-private partnership), are issued on the USA market. These bond types have either state guarantees or guarantees of large commercial USA banks.

Indian companies place loans raised upon bonds and act as participants of PPP programs in the field of transport infrastructure. Besides infrastructure bonds, guarantees of the specified corporations under the obligations of PPP private participants are widely used in India. With the purpose to increase the attractiveness of ins infrastructure investment, the line of tax concessions is used in India. For example, such as income from infrastructure bonds are non-taxable, and companies participating in the project receive tax holidays for 10 years.

China is one of the largest investors investing in transport infrastructure development (8\% of national GDP). The structure of liabilities of China Development Bank (CDB), specialized in financing infrastructure projects, contains bonds due to which the main infrastructure projects of China are financed.

In Nigeria, for bond financing of long-term infrastructure projects of public-private partnership (PPP), critical assessment based on empirical, quantitative and qualitative and factor analysis, is used [9].

Beside infrastructure bonds, the world economy considers the use of project infrastructure bonds and credit default swaps (CDS) at the infrastructure financing in terms of public-private partnership [10].

Summing up the described international experience of placing infrastructure bonds, we should distinguish the following parties that seem to be useful for the similar instruments introduction in the Russian financial market:

- $\quad$ The infrastructure bonds have a long-term period to repayment from 5 to 30 years (the average range of the period to repayment is $15-20$ years);

- infrastructure bonds are mostly provided with state guarantees;

- investors into infrastructure bonds are mostly represented by pension funds, development banks and commercial banks, investment funds, and other large financial organizations;

- the state often presents in the stock structure of the main purchasers of infrastructure bonds.

To attract private investors to operating infrastructure bonds, it is recommended to implement the following criteria:

- $\quad$ project low risk and cash flow stability;
- $\quad$ legislative conformity of infrastructure bonds to the investment requirements set to pension funds, insurance companies, open unit trusts;

- $\quad$ state participation in the project;

- $\quad$ possibility of risk hedging under infrastructure bonds;

- availability of tax preferences for the project members.

After consideration of the experience of using bonds for infrastructure projects financing, it can be stated that this channel of attracting the investment is prospective, and that it is required to implement this channel for financing of already Russian projects. Moreover, similar bonds will contribute to the internal financial market consolidation [3].

Project financing. So far, the state lacks funds for satisfying the need for budget investment in the country scale. For this reason, the approach to PPP changed radically. If the state earlier was solving the task of reasonable spending of the sufficient funds, now its main task is attracting out-of-budget sources, private investments into the infrastructure development, providing the efficient start of the certain project with the budget availability. However, investments into infrastructure (not only transport), take long time to pay of, their profitability at the first stage is not as high as in projects in other economic sectors. In order to increase profitability and to decrease risks at the same time, they use various state support tools, known as the "state arm." But, actually, it is the classic project financing, higher availability of financial resources in which is provided through various forms of state guarantees, subsidies, guaranteed procurements, etc.

Project financing operation features In terms of investment project financing, it is necessary to create the project company for the implementation of the specific project in the form of the separate legal entity (special purpose vehicle, SPV). The main (and in most cases, the only) source of return of financing invested into the project are cash flows generated by the project itself, and assets created in the process of its implementation. In connection with this, at application consideration, banks pay the increased attention to the potential sales volume that should be proved by comfortable letters from potential customers. At project financing, there are no strict requirements to hard pledges and the need to create the excessive collateral value in the form of the initiators' personal securities, etc. Most often, there are no pledges, or their volume is limited, and can cover the entire credit volume not fully. Project financing of investment projects is target. Funds attracted can be spent only on cost items agreed before; the initiator cannot use them at his/her own disposal. One of the riskiest tools for the party that proves financing and its implementation requires a detailed examination from the financial institution side. In particular, banks pay the increased attention to the business essence and processes taking part in it. For this purpose, technical and economical justifications, marketing reports, financial models and business plans are prepared. Construction is the inseparable part of the 
- $\quad$ higher crediting rates before the project reaches the project capacity, high indirect cost, and fundraising commissions;

- $\quad$ need to finance the part of the project from the won funds or due to attracting the share investor.

Success factors:

- prospective business in an interesting area, presence of competitive advantages;

- high project development quality and the presence of bank risk minimization schemes;

- project professional team with the successful experience in similar business conduct;

- $\quad$ investment of minimum $20-30 \%$ own funds into the project.

The most optimal and actual scheme of project financing in current economic realia is the scheme given in Figure 2. partnership projects, the financial risk level should be kept in mind. The rather serious attention is paid in foreign studies to the simulation and the assessment of financial risks of the public-private partnership infrastructure project [8].

\section{FINAL STATEMENT - CONCLUSIONS OF THIS RESEARCH AND PROSPECTS FOR FURTHER DEVELOPMENT OF THIS DIRECTION}

A common misconception is to believe that the amount of own funds can be represented in the form of a property deposit, revaluation of land assets, justification of previously incurred expenditures, but in $99.9 \%$ of cases this does not work out, and it is required to look for hard cash, and often, to confirm their presence by buying the bank bill that will be immediately included into the collateral value. The role of the state is crucial in project implementation. Often, these are state guarantees, subsidies, concessionary conditions that become prerequisites for the project successful implementation. Advantages of financing real investment:

- in calculating the maximum credit amount, the forecast cash flows from the investment project implementation are taken into account, which allows attracting long-term debt financing in volumes greatly exceeding the scale of the company current activity; financing on the business initial stages is possible;

- financing on "without regression" or "with limited regression" is possible..

- Disadvantages of financing real investment:

- line of strict requirements to the presence of IPD for the project, quality of the project development, the composition of the project members, limitations for the company further activity;

considerable terms of the project consideration and the decision making by the bank (6-12 months);

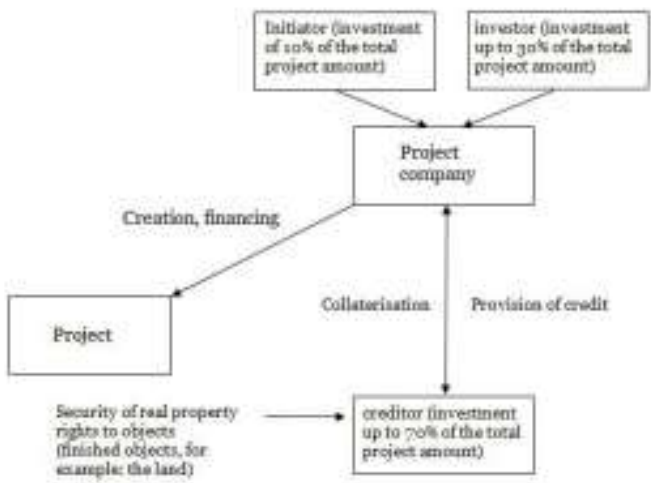

Figure 2 Project financing optimal scheme [2]

Project risk assessment is the first step towards its structuring and developing the project's financial and legal scheme (Figure 2). Project financing seems to be the most suitable financing model. It solves the main issue, i.e. investment attraction into the project; at this, exactly the project financing provides the largest number of tools to be used for the project implementation.

\section{REFERENCES}

[1] Federal Law of the Russian Federation "On State and Municipal Unitary Enterprises" dated November 14, 2002 No. 161-FZ: adopted by the State Duma on October 11, 2002 http://www.consultant.ru/

[2] N. A. Gosteva, The concession mechanism and other types of public-private partnership instruments in the creation and development of infrastructure special economic zones, Publishing house Financial University, 2012, 146 p.

[3] N. A. Polyakov, Experience and prospects of financing infrastructure projects in the Russian Federation, Bulletin of St. Petersburg State University. Series 5: Economics, 1 (2010). 
[4] KI Fioktistov, Trends in the interaction of government and business in the domestic economy, Moscow School of Economics, 2012, pp. 18-20.

[5] K. L Shevyolkina, Public-private partnership in the field of development of transport infrastructure, Motor transport enterprise, 7 (2012) 35-38.

[6] D. A. Shvelidze, Features of foreign participation in Russian public-private partnership projects, Management. Scientific notes of young researchers, 2 (2016)46-54.

[7] Western high-speed diameter [Electronic resource] https://nch-spb.com/about/

[8] Financing Risk Analysis and Case Study of Publicrivate Partnerships Infrastructure Project, Chen Zhendong, Yuan Jingfeng, Li Qiming, 20th International Symposium on Advancement of Construction Management and Real Estate, Hangzhou, PROCEEDINGS OF THE 20TH INTERNATIONAL SYMPOSIUM ON ADVANCEMENT OF CONSTRUCTION MANAGEMENT AND REAL ESTATE, 2017, pp.405-416.

[9] Barriers to bond financing for public-private partnership infrastructure projects in emerging markets A case of Nigeria, Babatunde, Solom on Olusola; Perera, Srinath, JOURNAL OF FINANCIAL MANAGEMENT OF PROPERTY AND CONSTRUCTION, 22(1) (2017) 2-19.

[10] Li Shuai; Abraham Darby, Cai Hubo, Infrastructure financing with project bond and credit default swap under public-private partnerships, INTERNATIONAL JOURNAL OF PROJECT MANAGEMENT, 35(3) (2017) 406-419 